\title{
Water Movement and Sea Temperature in the English Channel.
}

\author{
By
}

\author{
H. W. Harvey, M.A.,
}

Hydrographer at the Plymouth Laboratory.

With Two Diagrams in the Text.

DURING the last three years further evidence has been obtained that water of relatively high salinity, from the Atlantic to the south-west of the entrance, enters the English Channel past Ushant (1).

It is of interest to summarize this evidence in view of the suggestion (2) that the English Channel is cut off from the Atlantic for considerable periods.

The surface samples of very high-salinity water, collected in the Channel by the Ministry of Agriculture and Fisheries, suggest the possibility of masses of oceanic water moving into the Channel past Ushant from time to time; and they further suggest that this oceanic water divides in the western end of the Channel, one part moving direct into the North Sea, through Dover Straits, and the other part turning and passing out northward between Land's End and the Scillies. This is discussed by Mr. J. R. Lumby (see p. 670 of the present number of this Journal).

Drift-bottle experiments carried out by the Ministry of Agriculture and Fisheries show a movement of water from the Channel into the North Sea. This is discussed by Mr. J. N. Carruthers (see p. 665 of the present number of this Journal).

Besides carrying planktonic organisms with it and in this way affecting the distribution of the fauna, and besides causing variations in the concentration of the inorganic salts in solution which are necessary for plant growth (9), this inflow of water from the Atlantic has an effect upon the temperature of the water in the Channel, causing variations from the mean temperature of the month, such as will have a marked physiological effect upon the fauna.

In order to indicate the magnitude of this temperature effect the following observations are not out of place: A rise of temperature in the sea causes an increase in the rate of oxygen consumption and metabol- 
ism of most marine animals (3). This increase varies with the initial temperature, but within the limits within which the animal lives it is in the order of 10 to 15 per cent per degree of temperature. This presumably means that 10 to 15 per cent more food is required to repair waste. The similar magnitude of the effect of temperature on the velocity of ciliary and amœboid movement has been recorded (4), and indicates that the

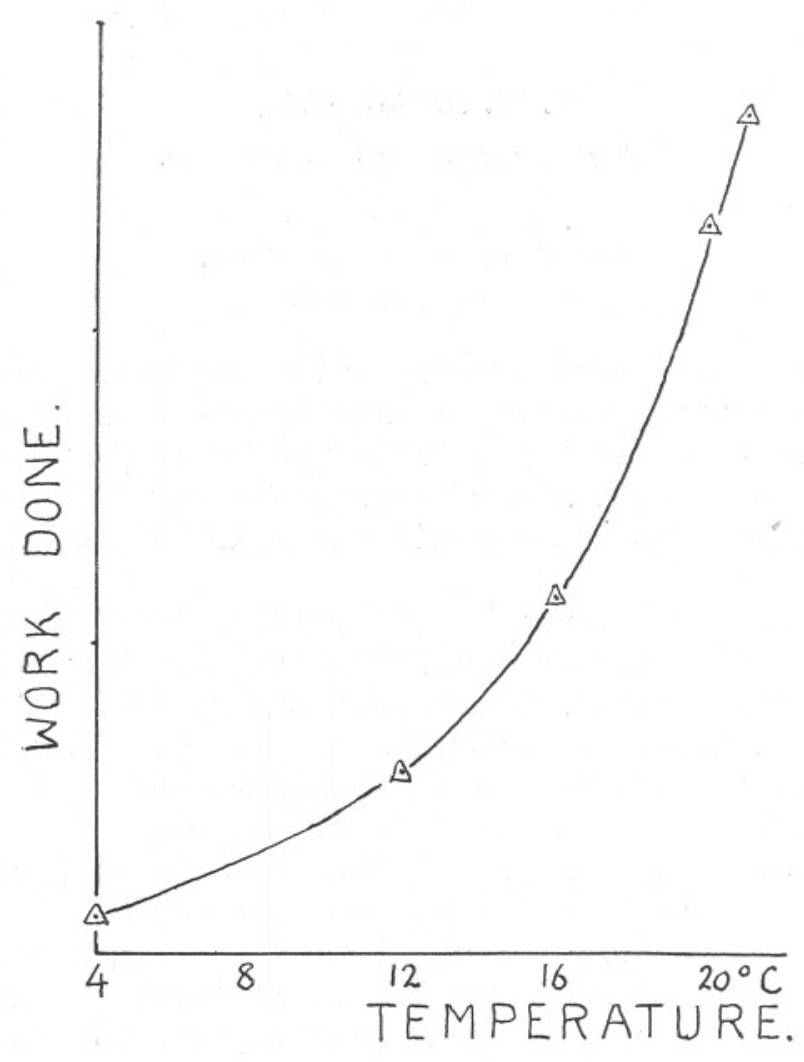

DIAGRAM A.

Relation between work done in unit time by excised heart of Maia squinado and temperature. (From kymograph record made by Dr. L. Hogben, July, 1924.)

capacity for movement of protoplasm is affected by temperature to much the same extent. This relatively enormous effect of temperature on the physiological processes in marine animals is also well illustrated by an experiment made in this Laboratory by Dr. L. Hogben and communicated to the writer. The excised heart of a Maia squinado was bathed with a saline solution at varying temperatures, and the rate and amplitude of the beat was recorded. At $4^{\circ} \mathrm{C}$. the heart practically ceased 
to beat, and above $21^{\circ} \mathrm{C}$. it appeared to be injured. At temperatures between $4^{\circ}$ and $21^{\circ} \mathrm{C}$. both rate and amplitude increased with rise in temperature.

The work done by the heart muscle in unit time will be approximately proportional to the product of the recorded amplitude of the beat multiplied by the number of beats per unit time, in this case where it is working against the weight of the recording lever. This product is plotted against temperature in Diagram A, and shows the magnitude of the temperature effect on the heart muscle.

These considerations indicate that, within the limits of temperature experienced by an animal in the sea, its "rate of living" is increased in the order of 10 to 15 per cent for every degree centigrade rise in

\section{TABLE I.}

\begin{tabular}{|c|c|c|c|c|}
\hline $\begin{array}{l}\text { Temperature } \\
\text { of Bottom } \\
\text { Water at E1. }\end{array}$ & 1921. & 1922. & 1923. & 1924. \\
\hline $\begin{array}{r}\text { Over } 15^{\circ} \mathrm{C} . \\
14^{\circ} \mathrm{C} . \\
13^{\circ} \mathrm{C} . \\
\text { Below } 11^{\circ} \\
10^{\circ} \\
9^{\circ}\end{array}$ & $\begin{array}{l}\text { Early Oct. to early } \\
\text { Nov. } \\
\text { Early Sept. to } \\
\text { early Dec. } \\
\text { Early July to mid. } \\
\text { Dec. } \\
\end{array}$ & $\begin{array}{l}\text { Never. } \\
\text { Mid. Sept. to mid. } \\
\text { Oct. } \\
\text { End Aug. to early } \\
\text { Nov. } \\
\text { End Jan. to end } \\
\text { June. } \\
\text { Early March to } \\
\text { mid. May. } \\
\text { Never. }\end{array}$ & $\begin{array}{l}\text { Never. } \\
\text { Never. } \\
\text { Mid. Sept. to mid. } \\
\text { Oct. } \\
\text { Mid. Dec., '22, to } \\
\text { end June. } \\
\text { Mid. Jan. to end } \\
\text { April. } \\
\text { Never. }\end{array}$ & $\begin{array}{l}\text { Never. } \\
\text { Late Sept. to end } \\
\text { Oct. } \\
\text { Early Dec., '23, to } \\
\text { early July. } \\
\text { Early Dec., '23, to } \\
\text { end May. } \\
\text { End Jan. to early } \\
\text { May. }\end{array}$ \\
\hline
\end{tabular}

temperature; its requirements-oxygen and food-are increased in proportion.

Orton (5) has shown that the breeding season of many marine animals lies within comparatively small limits of temperature. Variations in the temperature of the sea between one year and another may materially alter the duration and time of the breeding season. If the time of the breeding season is displaced it may cause the young to appear at a time when their natural food "is out of season," in those cases where the food consists of diatoms or is dependent upon diatoms whose growth is controlled by sunshine as well as by temperature (10).

That the fauna is exposed to a very different range of temperature from one year to another is well shown in Table $I$, which refers to the bottom water at Station E1, 22 miles south-west of Plymouth.

That an inflow of Atlantic water is one of the factors influencing the temperature of the sea in the Channel, is clearly shown by the observations made every month at the Station E1. During October and Novem- 
ber, 1921, there was a very rapid rise in salinity (6). On reference to Diagram B it is seen that the temperature of the ground and air had. fallen below that of the surface water of the sea by early October. The whole column of water, from top to bottom, continued to gain heat for a further three or four weeks. These two points together show

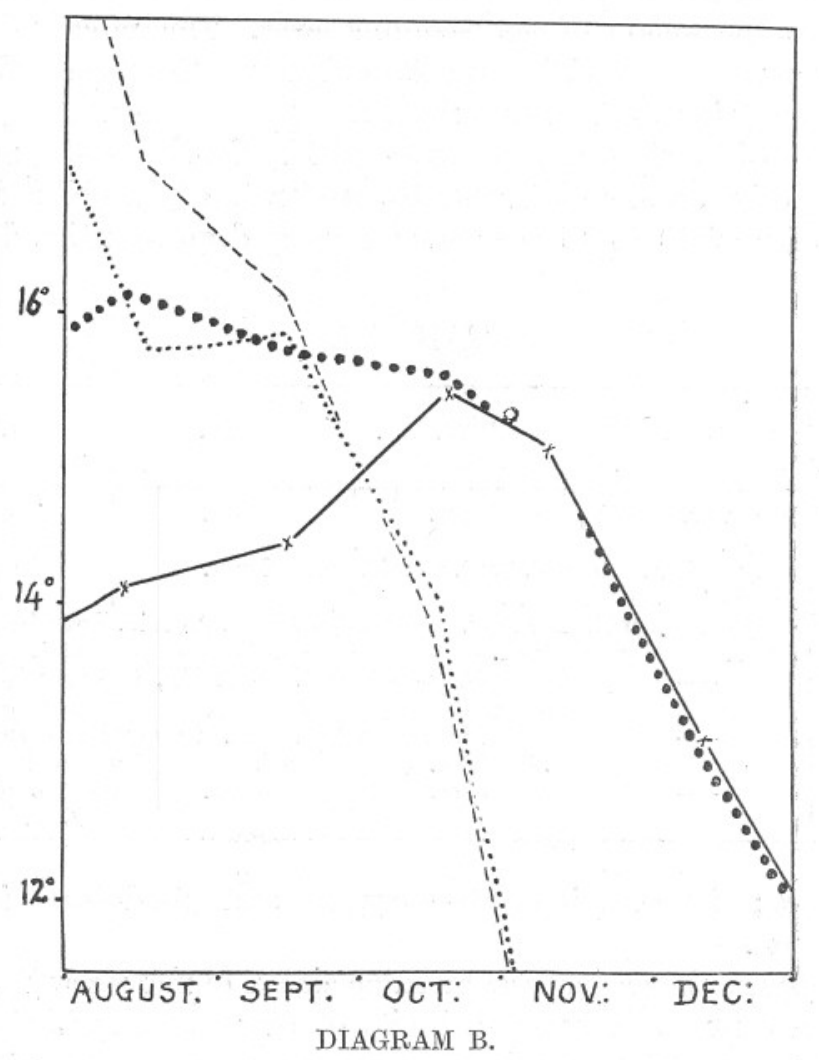

Station $\mathrm{E}_{1}, 1921$.

Thick line represents temperatures of a column of water at $\mathrm{E}_{1}$ from top to bottom, as if completely mixed, calculated from the temperatures observed at different depths. Heavy dotted line represents temperature of surface water at $\mathrm{E}_{1}$.

Fine dotted line represents mean air temperature on Plymouth Hoe. Hoe.

Pecked line represents mean ground temperature 1 foot below surface on Plymouth

that warmer water entered the area. Its salinity was characteristic of water occurring earlier in the year south-west of the entrance to the Channel.

During the same period in 1922 and 1923 there was no indication of any such considerable inflow of oceanic water at this station. 
Furthermore, there is evidence that the loss of heat which occurred was largely controlled by local meteorological conditions ( $\boldsymbol{y})$.

Fig. 1, p. 679, of this Journal shows the variation in temperature of a column of water from top to bottom at E1. It is a fair curve drawn through points which were arrived at by calculating (integrating) the temperature of the whole column from the temperatures observed at a series of different depths, at each date when the Station was worked. It is possible, from it, to arrive at a very fair approximation of the temperature of the column at the middle of each month.

The following temperatures for the middle of the autumn months in 1921, 1922, and 1923 were obtained in this way.

$\begin{array}{cccccc} & 1921 . & 1922 . & \begin{array}{c}\text { Difference. } \\ 1921-1922 .\end{array} & 1923 . & \begin{array}{r}\text { Difference. } \\ 1922-1923 .\end{array} \\ \text { Mid. September } & 14 \cdot 4 & 14 \cdot 3 & 0 \cdot 1 & 13 \cdot 6 & 0 \cdot 7{ }^{\circ} \mathrm{C} \text {. } \\ \text { ", October } & 15 \cdot 4 & 13 \cdot 9 & 1 \cdot 5 & 13 \cdot 4 & 0 \cdot 5 \\ \text { ", November } & 14 \cdot 7 & 11 \cdot 8 & 2 \cdot 9 & 11 \cdot 9 & -0 \cdot 1 \\ \text {, December } & 12 \cdot 9 & 10 \cdot 9 & 2 \cdot 0 & 10 \cdot 2 & 0 \cdot 7\end{array}$

Comparing 1921 with 1922, a very marked difference occurs suddenly in October and November, due to the inflow of water in 1921. Comparing 1922 and 1923 in the same way no such sudden marked difference occurs.

An inspection of the curve shown in Fig. 1, p. 679, leads to the conclusion that the inflow of oceanic water raised the temperature of the water in this area $11_{2}^{\circ} \mathrm{C}$. or more above what would have been its probable temperature in October, November, and December if no such inflow had occurred.

\section{REFERENCES.}

1. D. J. Matthews. Physical Conditions in the English Channel, 1904-1906. 2nd Report (Southern Area) Internat. Invs. Mar. Biol. Assoc. Cd. 4641. London, 1909.

Ditto, 1906, 3rd Report, Cd. 5546. London, 1911.

2. E. Le Danois. Annales de l'Institut Oceanographique-Nouvelle Serie-Tome I, Fasc. 1, 1924, pp. 36, 37. Notes et Memoires, No. 36. Paris, 1924.

3. A. Krogh. Respiratory Exchange. Monographs on Biochemistry. Publ. Longmans, 1916, p. 87. 
4. J. Gray. Mechanism of Ciliary Movement. Proc. Roy. Soc., 95, p. 6. May, 1923.

C. F. A. Pantin. On the Physiology of Amœboid Movement II. Effect of Temperature. Brit. Journ. Exper. Biology., Vol. I, July, 1924.

5. J.H. Orton. Sea Temperature, Breeding and Distribution in Marine Animals. Journ. Mar. Biol. Assoc., Vol. XII, No. 2, p. 339 et seq. July, 1920.

6. H. W. Harvey. Journ. Mar. Biol. Assoc., Vol. XIII, No. 1, p. 230. Nov., 1923.

7. — Journ. Mar. Biol. Assoc., Vol. XIII, No. 3, p. 678.

9. W. R. G. Atkrns. Journ. Mar. Biol. Assoc., Vol. XIII, No. 1, p. 119. Nov., 1923.

10. E. J. Allen and E. W. Nelson. On the Artificial Culture of Marine Plankton Organisms. Quarterly Journal Microscopical Science, Vol. 55, Part 2. June, 1910. 